\title{
Preparación y caracterización antimicrobiana de péptidos encapsulados en suportes biopolimericos con una potencial aplicación biotecnológica
}

\author{
Preparation and Characterization of Antimicrobial Peptides Encapsulated in Biopolymeric \\ Supports, with Potential Biotechnological Application
}

\author{
Islas C.J. ${ }^{a}$, López C.M. del R. ${ }^{a}$, Rodríguez H.A.I ${ }^{a}$, Martínez J.V.M. ${ }^{a}$, Chavarría H.N. ${ }^{a}$
}

\begin{abstract}
:
Antimicrobial peptides have been widely examined as possible conservatives in food. However, low stability, proteolytic degradation, interaction with the environment, possible interaction of the antimicrobial peptide with food components could reduce antimicrobial activity. The encapsulation of bacteriocins in liposomes could represent an alternative to overcome the problems related to stability and degradation; similarly releasing of the active compounds would be slower compared to that of an unprotected compound. It is frequently reported that the encapsulation of bacteriocins in liposomes is achieved by the thin film hydration method, being phosphatidylcholine, the most common phospholipid used in the manufacture of liposomes. The purpose of this work was to study conventional liposomes and stealth liposomes obtained by hydration method of the film, and its characterization.
\end{abstract}

Keywords:

Oxalis tuberosa, extracts, antioxidant activity

Resumen:

Los péptidos antimicrobianos han sido ampliamente examinados como posibles conservadores en alimentos. Sin embargo, los problemas de estabilidad, la degradación proteolítica, interacción con el medio ambiente, la posible interacción del péptido antimicrobiano con los componentes de los alimentos podría reducir la actividad antimicrobiana. El encapsulamiento de bacteriocinas en liposomas podría representar una alternativa para superar los problemas relacionados con estabilidad y degradación; de igual manera la liberación del compuesto activo seria lenta en comparación con un compuesto sin protección. Frecuentemente la encapsulación de bacteriocinas en liposomas se logra mediante el método de hidratación de película delgada, siendo la fosfatidilcolina el fosfolípido más común empleado en la fabricación de liposomas. Este trabajo se enfoca en la elaboración de liposomas convencionales y liposomas stealth por el método de hidratación de película, y su caracterización.

\section{Palabras Clave:}

Liposomas, biopolimeros, nisina, potencial Zeta, pectina, chitosan

\section{Introduction}

During recent years trends in consumers have been observed for the search of healthy products, minimally processed and containing natural preservatives, since the inadequate use of conventional preservatives, poor food handling and unsatisfactory processing practices can lead to the proliferation of pathogenic and / or deteriorating microorganisms, being able to generate health problems with important economic implications. Among other alternatives to solve this problem, we have the bioconservation, which is the extension of the useful life and increase the safety of a food, using its natural or controlled microbiota, and its metabolites (Patrícia da Silva Malheiros, Daroit, \& Brandelli, 2010). Numerous antimicrobials synthesized by microorganisms have been studied to prevent food contamination, although their effectiveness as antimicrobials for the control of contaminants in food is widely proven, there are obvious limitations including undesirable flavors, compound 
instability, low solubility, among others (Zou, Lee, Seo, \& Ahn, 2012).

Between the natural bioconservatives are the antimicrobial peptides (bacteriocins), such as nisin, discovered more than 50 years ago, being recognized as GRAS (generally recognized as safe) is used as preservative in more than 40 countries, it is a polypeptide of 34 amino acids with antimicrobial power, is synthesized ribosomally by Lactococcus lactis, and inhibits Gram positive microorganisms and in combination with other agents can also inhibit Gram negatives (Cotter, 2005) its use in the industry is increasing, because it could be released quickly depending on the food matrix, its conservative effect can be active only in short periods, in addition to its antimicrobial effect is diminished by interacting with components present in the food. An alternative to this drawback is the encapsulation of nisin, in this way the release of bacteriocins in the feed could be gradual and sustained, offering a longer shelf life (Were, Bruce, Davidson, \& Weiss, 2004).

The encapsulation has been used for the purpose of adding value to the product, through protection and transport, or through the controlled release of the active agent $(\mathrm{AA})$ in a suitable time and place, improving the effectiveness of the additives and expanding its applications (Gouin, 2004). There are several methods of encapsulation of A.A, which can be physical processes and chemical processes such as liposomes.

Liposomes are vesicles composed mainly of bilayer phospholipids, contain an internal aqueous phase and are suspended in another external aqueous phase, their formation occurs instantaneously when the phospholipids are mixed with water; its polar part interacts with water, and its apolar part interacts with its homologues (fatty acids) to form bilayers. Liposomes have been occupied as transporters of therapeutic agents, and continue to be studied to monitor the controlled release of drugs, enzymes, antioxidant vitamins and flavorings (Jesorka \& Orwar, 2008).

Liposomes can be classified by their size into small $30-100$ $\mathrm{nm}$, large $100-500 \mathrm{~nm}$ and giant $600-3500 \mathrm{~nm}$; by their number of bilayers in oligolamellar (2 layers) or multilamellar (more than 2 layers), by the inclusion of vesicles (liposomes inside other larger liposomes) and by their type of component, like synthetic liposomes, liposomes with antigen and stealth liposomes (Jesorka \& Orwar, 2008).

There are different techniques for the preparation of liposomes, such as extrusion, reverse phase, lyophilization, among others; but the hydration method of the film is the most used for the encapsulation of antimicrobial peptides (Brandelli, 2012), since it is cheap and easy to prepare. Some modifications have been suggested to improve the stability of liposomes, such as the inclusion of cholesterol and / or fatty acids, the inclusion of cationic or anionic compounds and the polymer coating (stealth liposomes) (Ulrich, 2002).

Biopolymers such as polysaccharides are widely used in the food, pharmacy and cosmetics industries. Pectin is an example of a biopolymer that receives attention from different areas of research, is an anionic polysaccharide comprising a linear main chain composed of units of galacturonic acid linked by $\alpha-1 / 4$ bonds (Lopes, Pinilla, \& Brandelli, 2017). The advantage of using pectin in the development of nanoparticles is due to its biocompatibility, absence of toxicity and biodegradability, which allows incorporation into a wide range of commercial products (Nguyen, Alund, Hiorth, Kjoniksen, \& Smistad, 2011). Chitosan is another biopolymer, of cationic nature and is formed by units of D-glucosamide and N-acetyl-Dglucosamide, it is a good candidate for the liposome coating, because it does not present toxicity and is biodegradable (Zohri et al., 2010).

Regarding the stability of the liposomes, the Zeta potential is usually used as an indicator for accessible charges on liposomal surfaces, this measures the forces of repulsion or attraction of the particles, indicating stability in the suspension, it has been reported that at values greater than $\pm 25 \mathrm{mV}$, the suspension is stable and the suspensions are unstable at values close to 0 (Patrícia da Silva Malheiros, Micheletto, Silveira, \& Brandelli, 2010), there are reports in which liposomes have been prepared with neutral phospholipids such as phosphatidylcholine (PC ) and report $Z$ potential values of $-8 \mathrm{mV}$, but when adding a polymer such as pectin it increases up to $-25 \mathrm{mV}$ (Lopes et al., 2017), which gives an improvement to its stability, in the same way have made liposomes with cationic phospholipids, from the beginning the lipids give a charge to the liposome generating repulsion between particles and the suspension is maintained stable. There are reports using mixtures of lipids such as PC and phosphatidylglycerol to generate cationic or anionic liposomes (P. da Silva Malheiros, Daroit, da Silveira, \& Brandelli, 2010, Were et al., 2004).

The efficiency of entrapment of nisin in liposomes is reported in different works, for liposomes elaborated from raw lecithin they reported a 92\% entrapment (Patrícia da Silva Malheiros, Yasmine Miguel Serafini Micheletto, et al., 2010), for liposomes with PC of commercial grade of $70 \%$ of entrapment (Zou et al., 2012), likewise there are reports of liposomes covered with chitosan and chondroitin sulfate with a $67 \%$ entrapment (da Silva, Boelter, da Silveira, \& Brandelli, 2014 ), liposomes with pectin show entrapments close to $94 \%$ (Lopes et al., 2017)

In the present work, conventional liposomes and stealth liposomes were elaborated from purified lecithin, exhibiting an average size of $150 \mathrm{~nm}$ to $210 \mathrm{~nm}$, which enter the classification of large liposomes; the average $Z$ power was 
$-52 \mathrm{mV}$ to $+24 \mathrm{mV}$, suggesting stable suspensions; the encapsulation efficiency was $87 \%$ to $95 \%$.

\section{Referencias}

Brandelli, A. (2012). Nanostructures as Promising Tools for Delivery of Antimicrobial Peptides. Mini-Reviews in Medicinal Chemistry, Vol. 12, No. 8, 731-741.

Cotter, P., Hill, C., Ross, R.P. (2005). BACTERIOCINS DEVELOPINGINNATE IMMUNITY FOR FOOD. NATURE REVIEWS | MICROBIOLOGY, 3, 1-12. doi: 10.1038/nrmicro1240

da Silva, I. M., Boelter, J. F., da Silveira, N. P., \& Brandelli, A. (2014). Phosphatidylcholine nanovesicles coated with chitosan or chondroitin sulfate as novel devices for bacteriocin delivery. Journal of Nanoparticle Research, 16(7). doi: 10.1007/s11051-014-2479-y

da Silva Malheiros, P., Daroit, D. J., \& Brandelli, A. (2010). Food applications of liposome-encapsulated antimicrobial peptides. Trends in Food Science \& Technology, 21(6), 284-292. doi: 10.1016/j.tifs.2010.03.003

da Silva Malheiros, P., Daroit, D. J., da Silveira, N. P., \& Brandelli, A (2010). Effect of nanovesicle-encapsulated nisin on growth of Listeria monocytogenes in milk. Food Microbiol, 27(1), 175-178. doi: 10.1016/j.fm.2009.09.013

da Silva Malheiros, P., Micheletto, Y. M. S., Silveira, N. P. d., \& Brandelli, A. (2010). Development and characterization of phosphatidylcholine nanovesicles containing the antimicrobial peptide nisin. Food Research International, 43(4), 1198-1203. doi: 10.1016/j.foodres.2010.02.015

Gouin, S. (2004). Microencapsulation. Trends in Food Science \& Technology, 15(7-8), 330-347. doi: 10.1016/j.tifs.2003.10.005

Jesorka, A., \& Orwar, O. (2008). Liposomes: technologies and analytical applications. Annu Rev Anal Chem (Palo Alto Calif), 1, 801-832. doi: 10.1146/annurev.anchem.1.031207.112747

Lopes, N. A., Pinilla, C. M. B., \& Brandelli, A. (2017). Pectin and polygalacturonic acid-coated liposomes as novel delivery system for nisin: Preparation, characterization and release behavior. Food Hydrocolloids, 70, 1-7. doi: 10.1016/j.foodhyd.2017.03.016

Nguyen, S., Alund, S. J., Hiorth, M., Kjoniksen, A. L., \& Smistad, G (2011). Studies on pectin coating of liposomes for drug delivery. Colloids Surf B Biointerfaces, 88(2), 664-673. doi: 10.1016/j.colsurfb.2011.07.058

Ulrich, S. A. (2002). Biophysical Aspects of Using Liposomes as Delivery Vehicles. Bioscience Reports, 22, 1-22.

Were, L. M., Bruce, B., Davidson, P. M., \& Weiss, J. (2004). Encapsulation of Nisin and Lysozyme in Liposomes Enhances Efficacy against Listeria monocytogenes. Journal of Food Protection, 67(5), 922-927. doi: $10.4315 / 0362-028 x-67.5 .922$

Zohri, M., Alavidjeh, M. S., Haririan, I., Ardestani, M. S., Ebrahimi, S. E., Sani, H. T., \& Sadjadi, S. K. (2010). A Comparative Study Between the Antibacterial Effect of Nisin and Nisin-Loaded Chitosan/Alginate Nanoparticles on the Growth of Staphylococcus aureus in Raw and Pasteurized Milk Samples. Probiotics Antimicrob Proteins, 2(4), 258266. doi: 10.1007/s12602-010-9047-2

Zou, Y., Lee, H. Y., Seo, Y. C., \& Ahn, J. (2012).

Enhanced antimicrobial activity of nisin-loaded liposomal nanoparticles against foodborne pathogens. J Food Sci,

77(3), M165-170. doi: 10.1111/j.1750-3841.2011. 02580.x 